\title{
Evolutionary Game Analysis of Product Innovation Strategy between Two Competitor-oriented Companies
}

\author{
Wang Sili \\ Faculty of Management and Economics, Dalian University of Technology, Dalian, China
}

Dong Dahai

Faculty of Management and Economics, Dalian University of Technology;

China Business Executives Academy, Dalian, China

Meng Jiajia

Sun Wah International Business School, Liaoning University, Shenyang, China

\begin{abstract}
The existing research on product innovation mainly focused on the impact factors, paths and impact effects, etc.. However, the topic of how a company chooses product innovation strategy to cope with the competitor's is rarely studied. This article uses evolutionary game theory approach to model and study the choice of product innovation strategy between two competitor-oriented companies. Game analysis results show that evolutionary stable strategies exist in four scenarios and radical product innovation strategy is the only way to realize long-term development of the companies and market. In order to win in the competition, companies should adopt specific product strategy according to different situations, and they should pay more importance to radical product innovation strategy to maintain long-term competitive advantage.

KEYWORD: radical innovation product strategy; incremental innovation product strategy; competitororiented companies; evolutionary game analysis component
\end{abstract}

\section{INTRODUCTION}

In knowledge economy era, companies are in fierce competition of product innovation in order to meet the changing demands of customers and keep the competitive advantage. The mobile market is a typical example. Nokia, Apple and Samsung adopt different innovation strategy in the competition. As a result, Apple won with the disruptive innovation product and Samsung won with the incremental innovation product. This means both disruptive and incremental innovation products can help companies to keep their own competitive advantage in changing market. So in business practice, how should companies choose their own product strategy to deal with the competitors'? The problem can be studied using evolutionary game theory by simplify the competitors and boundary conditions. This paper excludes the affecting factors of customer orientation and cross department cooperation, and limits the research in two competitor-oriented companies. By using the theory of evolutionary game, this paper studied the product strategy choice problem between two competitor-oriented companies.

\section{LITERATURE REVIEW}

According to the different degree of technological change, product innovation can be divided into radical product innovation and incremental product innovation (Ettlie, 1986; Hou, 2007). Radical product innovation is a major technological breakthrough product innovation. It makes the products, services, technology and other features with unprecedented features, or have similar features but has a huge performance and cost improvement, or create a totally new product (Vadim,2001). Incremental product innovation is based on the company's existing technology, policies and practices to improve and extend the existing products or product lines. It generally manifests as small or simple technical adjustments which have some improvement on performance but do not change the basic product type itself. (Hou, 2007). Accordingly, the results of the two product innovation strategy are named radical innovations product and incremental innovation product.

Radical and incremental innovation strategy have big differences on products $R \& D$ investment, risks, life cycle and market effect. Compared with radical product innovation, incremental product innovation have clear objectives and target market thus have fewer R\&D cost, smaller failure risk and shorter development cycle. However, because there are no 
major technical changes, just the functionality extension and technological improvements of the original product, the impact on the market is relatively small. On the contrary, radical innovation requires companies to continuously take advantage of new technological achievements, seeking new ways to solve problems. If it succeeds, the original technology could be replaced, thus has breakthrough effect on the market (Liang Jun, 2004). Therefore, radical innovation strategy has the feature of larger investment, bigger risk, higher returns and long-term effects. While incremental innovation strategy have the feature of smaller investment, lower risk, lower returns and short-term effects.

Currently, research on product innovation strategy mainly focused on product innovation strategy itself, that is the impact factors, paths and impacting effects, etc..Approach from the perspective of a competitor's product strategy selection is very few. Competitor-orientation is the activities of obtaining the information of competitors and proliferating it within the organization (Narver and Slater, 1990; Du Yunzhou, etc., 2012). Company's competitororiented strategy will cause reactions of competitors (Chen, 1996), thus it is suitable to use evolutionary game theory to study the problem. Of the existing researches based on evolutionary game, Bi Kexin, Sun Dehua (2010) researched on the joint development of product innovation department and process innovation department in manufacturing industry companies on product innovation and process innovation. The study created the cost model strategy selection of the two innovation types in different conditions. Fu Xiaoyong (2011, 2012) chose the government's scrap electronics recyclers as game objects and explored the optimized solution for recyclers and how government regulate recyclers' dismantling ways under different conditions which is a good reference for the decision-making of governments.

Through the above literature review, we can find that the aspects of the existing researches are from the selection of company's internal innovation strategy and strategic choice between the government and recyclers of the regulatory relationship. There's few research of product innovation strategy between two competitive companies. Facing the launch of the radical or incremental innovation products of competitors which could break the original competitive situation, what product strategy should companies choose has become an important issue fatal to business survival. Therefore, this paper used evolutionary game method to establish game model of product innovation strategy selection between two competitors to seek the best product strategy choice under different market environment.

\section{EVOLUTIONARY GAME MODEL AND HYPOTHESIS}

\subsection{Model notations}

The main indicator and parameter definition are listed in table 1.

Table 1 Model notation definition

\begin{tabular}{|c|c|}
\hline Notation & Definition \\
\hline$C_{a l}$ & $\begin{array}{l}\text { Cost of company a by choosing radical product } \\
\text { innovation strategy }\end{array}$ \\
\hline$C_{a 2}$ & $\begin{array}{l}\text { Cost of company a by choosing incremental product } \\
\text { innovation strategy }\end{array}$ \\
\hline$C_{b l}$ & $\begin{array}{l}\text { Cost of company } b \text { by choosing radical product } \\
\text { innovation strategy }\end{array}$ \\
\hline$C_{b 2}$ & $\begin{array}{l}\text { Cost of company } b \text { by choosing incremental product } \\
\text { innovation strategy }\end{array}$ \\
\hline$R_{a}$ & $\begin{array}{l}\text { Revenue of company } a \text { when both company } a \text { and } b \\
\text { choose radical product innovation strategy }\end{array}$ \\
\hline$R_{b}$ & $\begin{array}{l}\text { Revenue of company } b \text { when both company } a \text { and } b \\
\text { choose radical product innovation strategy }\end{array}$ \\
\hline$P_{a}$ & $\begin{array}{l}\text { Revenue of company } a \text { when both company } a \text { and } b \\
\text { choose incremental product innovation strategy }\end{array}$ \\
\hline$P_{b}$ & $\begin{array}{l}\text { Revenue of company } b \text { when both company } a \text { and } b \\
\text { choose incremental product innovation strategy }\end{array}$ \\
\hline$W_{a}$ & $\begin{array}{l}\text { Revenue of company } a \text { when company } a \text { choose radical } \\
\text { product innovation strategy and company } b \text { choose } \\
\text { incremental product innovation strategy }\end{array}$ \\
\hline$W_{b}$ & $\begin{array}{l}\text { Revenue of company B when company a choose radical } \\
\text { product innovation strategy and company } b \text { choose } \\
\text { incremental product innovation strategy }\end{array}$ \\
\hline$M_{a}$ & $\begin{array}{l}\text { Revenue of company } a \text { when company } a \text { choose } \\
\text { incremental product innovation strategy and company } b \\
\text { choose radical product innovation strategy }\end{array}$ \\
\hline$M_{b}$ & $\begin{array}{l}\text { Revenue of company } b \text { when company } a \text { choose } \\
\text { incremental product innovation strategy and company } b \\
\text { choose radical product innovation strategy }\end{array}$ \\
\hline$X$ & $\begin{array}{l}\text { The probability of company a choose radical product } \\
\text { innovation strategy is } X \text {, choose incremental product } \\
\text { innovation strategy is } 1-X\end{array}$ \\
\hline Y & $\begin{array}{l}\text { The probability of company } b \text { choose radical product } \\
\text { innovation strategy is } \mathrm{Y} \text {, choose incremental product } \\
\text { innovation strategy is } 1-\mathrm{Y}\end{array}$ \\
\hline
\end{tabular}

\subsection{Model hypothesis}

The selection of company's product strategy has many constraint factors. In order to facilitate the analysis, we make the following assumptions:

1) The two parties are company $a$ and $b$. They are competitors. Both sides have limited rationality in the market and the choice of their game strategies is to maximize their own business interests.

2) Product strategies of the two parties. Company's product strategy includes launching radical innovation product or incremental innovation product. The successful launch of product by one company will seize the market share of the other's.

3) Strategy combination of the two parties. Which product strategy to take can be seen as the result of the game with its competitor. Because of the information asymmetry and bounded rationality between the two parties, it is difficult to accurately 
know the competitor's choice and maximize the own benefit when making decisions. Therefore, company $a$ may choose either to launch radical innovation products or incremental innovation products. Same with company $\mathrm{B}$. The product strategy game matrix is shown in Table 2 .

4) Earnings of the two parties. Because incremental innovation has the features of smaller investment, lower risk, lower return and short-term effects; while radical innovation has the features of bigger investment, higher risks, higher rewards and long-term effects, so $C_{a 1}>C_{a 2}, C_{b 1}>C_{b 2}, W_{a}>R_{a}$, $W_{b}>R_{b}, P_{b}>W_{b}, P_{a}>W_{a}, M_{b}>P_{b}, M_{b}>R_{b}$. The revenue indicator is related with customer acceptance. The game earning matrix is shown in Table 3.

Table 2 Strategy matrix of the two parties

\begin{tabular}{|c|c|c|c|}
\hline \multicolumn{2}{|c|}{ Game two parties } & \multicolumn{2}{c|}{ Company a } \\
\cline { 3 - 4 } & Radical & Incremental \\
\hline \multirow{3}{*}{ Company $b$} & Radical & (Radical, Radcal) & (Radical, Incrmental) \\
\cline { 2 - 4 } & Incremental & $\begin{array}{c}\text { (Incremental, } \\
\text { Radical) }\end{array}$ & $\begin{array}{c}\text { (Incremental, } \\
\text { Incremental) }\end{array}$ \\
\hline
\end{tabular}

Table 3 Earning matrix of the two parties

\begin{tabular}{|c|c|c|c|}
\hline \multicolumn{2}{|c|}{ Game two parties } & \multicolumn{2}{c|}{ Company a } \\
\cline { 3 - 4 } & Radical & Incremental \\
\hline \multirow{2}{*}{ Company $b$} & Radical & $R_{b}-C_{b 1} R_{a}-C_{a 1}$ & $M_{b}-C_{b 1}, M_{a}-C_{a 2}$ \\
\cline { 2 - 4 } & Incremental & $W_{b}-C_{b 2}, W_{a}-C_{a 1}$ & $P_{b}-C_{b 2}, P_{a}-C_{a 2}$ \\
\hline
\end{tabular}

\section{EVOLUTIONARY GAME MODEL OF THE TWO PARTIES' PRODUCT STRATEGIES}

In the initial stage of the game, the expected earnings of company $a$ takes radical and incremental product innovation strategy are $E_{a Y}$ and $E_{a N}$ respectively. The average earning is $\overline{E_{a}}$, So

$$
\begin{aligned}
& E_{a Y}=Y\left(R_{a}-C_{a 1}\right)+(1-Y)\left(W_{a}-C_{a 1}\right) \\
& E_{a v}=Y\left(M_{a}-C_{a 2}\right)+(1-Y)\left(P_{a}-C_{a 2}\right) \\
& \bar{E}_{a}=X\left[Y\left(R_{a}-C_{a 1}\right)+(1-Y)\left(W_{a}-C_{a 1}\right)\right]+ \\
& \quad(1-X)\left[Y\left(M_{a}-C_{a 2}\right)+(1-Y)\left(P_{a}-C_{a 1}\right)\right]
\end{aligned}
$$

According to reference [14-18], we can get the replicator dynamics equation of company $a$ from equation (1) and (3):

$$
\begin{aligned}
\frac{d X}{d t} & =X\left[Y\left(R_{a}-C_{a 1}\right)+(1-Y)\left(W_{a}-C_{a 1}\right)-X Y\left(R_{a}-C_{a 1}\right)-X(1-Y)\left(W_{a}-C_{a 1}\right)\right. \\
& \left.-Y(1-X)\left(M_{a}-C_{a 2}\right)-(1-X)(1-Y)\left(P_{a}-C_{a 2}\right)\right] \\
& =X(1-X)\left[W_{a}-P_{a}+C_{a 2}-C_{a 1}+Y\left(R_{a}+P_{a}-W_{a}-M_{a}\right)\right]
\end{aligned}
$$

The expected earnings of company B takes radical and incremental product innovation strategy are $E_{b Y} 、 E_{b N}$ respectively. The average earning is $\overline{E_{b}}$, So,

$$
\begin{aligned}
E_{b Y} & =X\left(R_{b}-C_{b 1}\right)+(1-X)\left(M_{b}-C_{b 1}\right) \\
E_{b N}= & X\left(W_{b}-C_{b 2}\right)+(1-X)\left(P_{b}-C_{b 2}\right) \\
\overline{E_{b}}= & Y\left[X\left(R_{b}-C_{b 1}\right)+(1-X)\left(M_{b}-C_{b 1}\right)\right] \\
& +(1-Y)\left[X\left(W_{b}-C_{b 2}\right)+(1-X)\left(P_{b}-C_{b 2}\right)\right]
\end{aligned}
$$

We can get the replicator dynamics equation of company B from equation (5) and (7) in the same way:

$$
\begin{aligned}
\frac{d Y}{d t} & =Y\left[X\left(R_{b}-C_{b 1}\right)+(1-X)\left(M_{b}-C_{b 1}\right)-X Y\left(R_{b}-C_{b 1}\right)-Y(1-X)\left(M_{b}-C_{b 1}\right)\right. \\
& \left.-X(1-Y)\left(W_{b}-C_{b 2}\right)-(1-Y)(1-X)\left(P_{b}-C_{b 2}\right)\right] \\
& =Y(1-Y)\left[M_{b}-C_{b}+C_{b 2}-C_{b 1}+X\left(R_{b}+P_{b}-M_{b}-W_{b}\right)\right]
\end{aligned}
$$

Equation (4) and (8) make up the dynamical system's replicator dynamics equation:

$$
\left\{\begin{array}{l}
\frac{d X}{d t}=X(1-X)\left[W_{a}-P_{a}+C_{a 2}-C_{a 1}+Y\left(R_{a}+P_{a}-W_{a}-M_{a}\right)\right] \\
\frac{d Y}{d t}=Y(1-Y)\left[M_{b}-P_{b}+C_{b 2}-C_{b 1}+X\left(R_{b}+P_{b}-M_{b}-W_{b}\right)\right]
\end{array}\right.
$$

\section{EVOLUTIONARY GAME ANALYSIS OF THE TWO PARTIES' PRODUCT STRATEGIES}

\subsection{Evolutionary stability analysis of the two parties' product strategies Footnotes}

Make $F(X)=\frac{d X}{d t}$, take derivative of the replicator dynamics equation(4) of company $a$ 's product strategy, we can get:

$$
\frac{d F(X)}{d t}=(1-2 X)\left[W_{a}-P_{a}+C_{a 2}-C_{a 1}+Y\left(R_{a}+P_{a}-W_{a}-M_{a}\right)\right]
$$

Evolutionary stability analysis for different ranges of parameters are as follows:

(1)When $W_{a}+M_{a}>R_{a}+P_{a}$ and $\frac{W_{a}-P_{a}+C_{a 2}-C_{a 1}}{W_{a}+M_{a}-R_{a}-P_{a}} \leq 1$
(1)When $Y=\frac{W_{a}-P_{a}+C_{a 2}-C_{a 1}}{W_{a}+M_{a}-R_{a}-P_{a}}, F(X)=0$, this means all $\mathrm{X}$ are in stable state. At this point, company $a$ can take any kind of product strategy, and it will not impact the company B's product strategy at all.

(2) When $\frac{W_{a}-P_{a}+C_{a 2}-C_{a 1}}{W_{a}+M_{a}-R_{a}-P_{a}}<Y \leq 1$, make $F(X)=0$, we can get $X=0, X=1$ are two stable state of $X$. According the stability of differential equation and the feature of evolutionary stability, when $\left.\frac{d F\left(X^{*}\right)}{d t}\right|_{X=x^{*}}<0, \quad X^{*}$ is stable state. From $\left.\frac{d F\left(X^{*}\right)}{d t}\right|_{X=0}>0$, $\left.\frac{d F\left(X^{*}\right)}{d t}\right|_{X=1}<0$ we can get that $X=0$ is the stable point, that is when the possibility of company B takes 
radical product innovation strategy higher than $\frac{W_{a}-P_{a}+C_{a 2}-C_{a 1}}{W_{a}+M_{a}-R_{a}-P_{a}}$ company $a$ 's best choice is radical product innovation strategy.

(3) When $0<Y<\frac{W_{a}-P_{a}+C_{a 2}-C_{a 1}}{W_{a}+M_{a}-R_{a}-P_{a}}$, from $\left.\frac{d F\left(X^{*}\right)}{d t}\right|_{X=0}<0$, $\left.\frac{d F\left(X^{*}\right)}{d t}\right|_{X=1}>0$, we can get that $X=1$ is the stable point. That is when the possibility of company B takes radical product innovation strategy lower than $\frac{W_{a}-P_{a}+C_{a 2}-C_{a 1}}{W_{a}+M_{a}-R_{a}-P_{a}}$

$\frac{W_{a}-P_{a}+C_{a}-C_{a}}{W_{a}+R_{a}-P_{a}}$, company A should choose incremental product innovation strategy.

(2) When $W_{a}+M_{a}>R_{a}+P_{a}$ and $\frac{W_{a}-P_{a}+C_{a 2}-C_{a 1}}{W_{a}+M_{a}-R_{a}-P_{a}}$, from $\left.\frac{d F\left(X^{*}\right)}{d t}\right|_{X=0}>0,\left.\quad \frac{d F\left(X^{*}\right)}{d t}\right|_{X=1}<0$ we can get that $X=1$ is the stable point, company A will choose radical product innovation strategy. Through simplify the equation we get $R_{a}-C_{a 1}>M_{a}-C_{a 2}$, that means when company $B$ takes radical product innovation strategy, the income of company A takes radical product innovation strategy is bigger than takes incremental product innovation strategy. So company A should choose incremental product innovation strategy for self-interest maximization.

(3)When $W_{a}+M_{a}<R_{a}+P_{a}$, from $\left.\frac{d F\left(X^{*}\right)}{d t}\right|_{X=0}>0,\left.\frac{d F\left(X^{*}\right)}{d t}\right|_{X=1}<0$, we can get that $X=1$ is the stable point. Company $a$ will choose radical product innovation strategy. This means when company $a$ 's income of choosing different product strategy is less than choosing the same, no matter which product strategy company choose, the best choice of company A is always radical product innovation strategy.

In the same way we can get company B's product strategy. Evolutionary stable strategy of the game model shows in table 4 . In the game, there are four evolutionary stable strategies. Both company $a$ and company B have two stable strategies.

Table 4 Evolutionary stable strategy of the game model

\begin{tabular}{|c|c|c|}
\hline Object & Condition & Evolutionary stable strategy \\
\hline \multirow{2}{*}{$\begin{array}{l}\text { Company } \\
a\end{array}$} & $\begin{array}{l}W_{a}+M_{a}>R_{a}+P_{a} \text { and } \\
\frac{W_{a}-P_{a}+C_{a 2}-C_{a 1}}{W_{a}+M_{a}-R_{a}-P_{a}}>1\end{array}$ & $\begin{array}{l}X=1 \text { is the stable point, company } \\
\text { A should choose radical product } \\
\text { innovation strategy }\end{array}$ \\
\hline & $W_{a}+M_{a}<R_{a}+P_{a}$ & $\begin{array}{l}X=1 \text { is the stable point, company } \\
\text { A should choose radical product } \\
\text { innovation strategy }\end{array}$ \\
\hline \multirow{2}{*}{$\begin{array}{l}\text { Company } \\
b\end{array}$} & $\begin{array}{l}W_{b}+M_{b}>R_{b}+P_{b} \text { and } \\
\frac{M_{b}-P_{b}+C_{b 2}-C_{b 1}}{W_{b}+M_{b}-R_{b}-P_{b}}>1\end{array}$ & $\begin{array}{l}Y=1 \text { is the stable point, company } \\
\text { B should choose radical product } \\
\text { innovation strategy }\end{array}$ \\
\hline & $W_{b}+M_{b}<R_{b}+P_{b}$ & $\begin{array}{l}Y=1 \text { is the stable point, company } \\
\text { B should choose radical product } \\
\text { innovation strategy }\end{array}$ \\
\hline
\end{tabular}

5.2 The evolutionary stability analysis of company a and $B$ 's strategies

According to replicator dynamics equation(9), we can get five replicator dynamics equilibrium point of product strategy between the two companies. They are $(1.0)(1.1)(0.0)(0.1)\left(\frac{M_{b}-P_{b}+C_{b 2}-C_{b 1}}{W_{b}+M_{b}-R_{b}-P_{b}} \cdot \frac{W_{a}-P_{a}+C_{a 2}-C_{a 1}}{W_{a}+M_{a}-R_{a}-P_{a}}\right)$. The result is only valid when $0 \leq \frac{M_{b}-P_{b}+C_{b 2}-C_{b 1}}{W_{b}+M_{b}-R_{b}-P_{b}} \leq 1$ and $0 \leq \frac{W_{a}-P_{a}+C_{a 2}-C_{a 1}}{W_{a}+M_{a}-R_{a}-P_{a}} \leq 1$. According to Friedman (1991), we know the equilibrium point is the necessary and sufficient condition of the stable point $\operatorname{det}(J)>0$ and $\operatorname{tr}(J)<0, \quad J=\left[\begin{array}{ll}\partial F(X) / \partial X & \partial F(X) / \partial Y \\ \partial F(Y) / \partial Y & \partial F(Y) / \partial Y\end{array}\right]$. Make $X_{0}=\frac{M_{b}-P_{b}+C_{b 2}-C_{b 1}}{W_{b}+M_{b}-R_{b}-P_{b}}, Y_{0}=\frac{W_{a}-P_{a}+C_{a 2}-C_{a 1}}{W_{a}+M_{a}-R_{a}-P_{a}}$, the analysis of the stability of equilibrium point show in table 5 .

From above analysis, we know that the system defined by function (9) has 4 saddle points and 1 stable point.According to Tan Zhengda etc.(2006) 's suggestion, phase path picture can be used to describe the dynamic evolution process of the system. And the dynamic evolution trend of two competitive companies' product strategy choice can be described with below Figure, Figure 1.

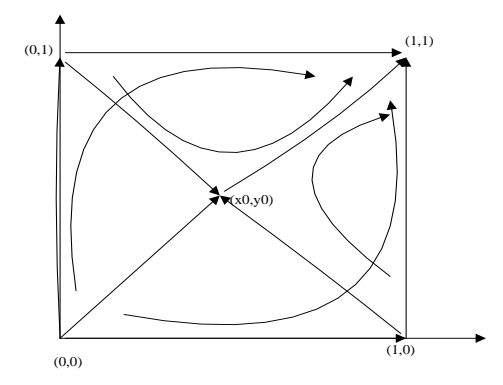

Figure 1 The dynamic evolution trend of two competitive companies' product strategy choice

\section{CONCLUSION}

This paper established the evolutionary game model of two competing companies. Comparing different equilibrium results, we can draw the following conclusions:

There are four evolutionary stable strategies in the game. Each company has two stable strategies as shown in Table 3.

In the following two scenarios, no matter what kind of strategy company B will take, company B should always take radical innovation strategy.

When $W_{a}+M_{a}>R_{a}+P_{a}$ and $\frac{W_{a}-P_{a}+C_{a 2}-C_{a 1}}{W_{a}+M_{a}-R_{a}-P_{a}}$, the scenario is when company $\mathrm{B}$ takes radical product innovation strategy, company $a$ 's revenue of taking 
radical product innovation strategy is higher than incremental product innovation strategy.

When $W_{a}+M_{a}<R_{a}+P_{a}$, the scenario is two companies take different product strategies, company $a$ 's revenue is less than both companies takes same product strategy.

In the following two scenarios, no matter what product strategy company A will take, company B should always take radical product innovation strategy.

When $\quad W_{a}+M_{a}>R_{a}+P_{a}$ and $\frac{W_{a}-P_{a}+C_{a 2}-C_{a 1}}{W_{a}+M_{a}-R_{a}-P_{a}}>1$, the scenario is when company $a$ takes radical product innovation strategy, company B's revenue of taking radical product innovation strategy is higher than incremental product innovation strategy.

When $W_{b}+M_{b}<R_{b}+P_{b}$, the scenario is two companies take different product strategies, company B's revenue is less than both companies takes same product strategy.

$$
\begin{aligned}
& \text { When } W_{a}+M_{a}>R_{a}+P_{a} \text { and } \frac{W_{a}-P_{a}+C_{a 2}-C_{a 1}}{W_{a}+M_{a}-R_{a}-P_{a}} \leq 1 \text {, or when } \\
& W_{b}+M_{b}>R_{b}+P_{b} \text { and } \frac{M_{b}-P_{b}+C_{b 2}-C_{b 1}}{W_{b}+M_{b}-R_{b}-P_{b}} \leq 1 \text {, there's no stable }
\end{aligned}
$$

evolutionary stable strategy. This means that the two game process manifests as a cycle mode. This situation exists in many companies' practice and it is a common phenomenon in real economy. Thus companies should determine the probability of each product strategies their competitors is going to take, based on which determine their own strategies.

Game of different initial conditions lead to different equilibrium outcome. What strategy the game parties finally choose depends on the proportion of their initial strategy to take, and this proportion is directly related to the benefit the strategy will bring. In the long term, as shown in Figure 1, only adhere to radical product innovation strategy will the two competing companies continually get higher revenue and better development.

From the above analysis, we can conclude that if the competitor-oriented companies want to remain invincible in the competition, they need to take the following strategies: 1) Fully understand customer needs. Only on the basis of understanding customer needs can company determine customer acceptance of new products and thus predict the income from new products; 2) Give consideration to both incremental and radical product innovation activities, and focus on promoting radical product innovation. Because under specific conditions, companies need to launch incremental innovation product to market in response to competitors, we cannot underestimate incremental innovation.
Launch incremental innovation product in the appropriate time can help companies get customers and open up new markets. From the long-term development trends, only adhere to radical product innovation can companies continuously launch new product to market to meet customer's needs, lead the market and maintain the competitive advantage.

\section{ACKNOWLEDGMENTS}

Thanks for the support by a grant from the National Natural Science Foundation of China Project (71272094) and the general project of Liaoning Province Department of Education Science Research (W2014008)

\section{REFERENCES}

[1] Jone. Ettlie, Willamp. Bridges and Robert D. O'Keefe. Organization Strategy and Structural Differences for Radical Versus Incremental Innovation. Management Science.1984, 6(30): 682695.

[2] HOU Jigang, LIU Yi, YANG Pianpian .The Impact Analysis of Supplier Involvement on Manufacturer's Product Innovation. Science of Science and Management of S. \& T., 2008(5)48-51.

[3] Liang Jun. Research of incremental innovation and radical innovation and evaluation methods Thesis of Zhongnan University, 2004.

[4] Narver,J. C. and S. F. Slater. The Effect of a Market Orientation on Business Profitability. Journal of Marketing, 1990(54): 20-35.

[5] Du Yunzhou, Zhang Yuli, Ren Bing. Show or hide a competitive advantage. Management World, 2012(7): 96-107.

[6] Chen,M.J. Competitor Analysis and Interfirm Rivalry: Toward a Theoretical Integration. Academy of Management Review, 1996(21): 100 -134.

[7] Bi Kexin, Sun Dehua. Game Analysis of Synergetic Development of Product Innovation and Process Innovation in Manufacturing Enterprises. Management Review, 2010(22):104-111.

[8] Fu Xiaoyong, Zhu Qinghua and Dou Yijie. Evolutionary Game Analysis of Governments and Electronic Manufacturers Based on the Implementation of WEEE Regulations, Management Review 2011, 10(23): 171-176.

[9] $\mathrm{Fu}$ Xiaoyong. Research on Game Models for Recycling and Treatment of Waste Electronic Products. Doctor Thesis of Dalian University of Technology, 2012.

[10] Friedman.D. Evolutionary Game in Economics. Econometrica. 1991.59(3):637-666.

[11] Friedman.D. On Economic Applications of Evolutionary Game. Theory Journal of Evolutionary Economics. 1998.8(1): 15-42.

[12] Herbert Gintis. Game Theory Evolving. American Princeton: Princeton University Press.2000.

[13] TAN Zhengda, WANG Wenping, TAN Yingzi. Evolutionary Game Analysis of Knowledge sharing Mechanism of Industrial Cluster. Operations research and management science, 2006, 15(2): 56-64. 